\title{
Online Foundation Course Program for First Year Medical Undergraduates Amidst the COVID-19 Pandemic - A New Learning Experience
}

\author{
Gitanjali Khorwal' \\ Gita Negi ${ }^{2}$ \\ Ashish Bhute ${ }^{3}$ \\ Harish Chandra ${ }^{4}$ \\ Priyavadhana Balasubramanian ${ }^{4}$ \\ Jayanti Pant ${ }^{5}{ }^{5}$ \\ 'Department of Anatomy, All India \\ Institute of Medical Sciences, Rishikesh, \\ Uttarakhand, India; ${ }^{2}$ Department of \\ Transfusion Medicine, All India Institute \\ of Medical Sciences, Rishikesh, \\ Uttarakhand, India; ${ }^{3}$ Department of \\ Forensic Medicine and Toxicology, All \\ India Institute of Medical Sciences, \\ Rishikesh, Uttarakhand, India; \\ ${ }^{4}$ Department of Pathology, All India \\ Institute of Medical Sciences, Rishikesh, \\ Uttarakhand, India; ${ }^{5}$ Department of \\ Physiology, All India Institute of Medica \\ Sciences, Rishikesh, Uttarakhand, India
}

Correspondence: Jayanti Pant Department of Physiology, All India Institute of Medical Sciences, Rishikesh, Uttarakhand, 249203, India

Email pant.jayanti@gmail.com

\begin{abstract}
Foundation programs are conducted in medical schools for undergraduate students, since they are naïve and unaware of the medical profession in depth. The program helps them to become familiar with the undergraduate medical training. The present intake of first year medical undergraduates had joined the institute amidst the COVID-19 pandemic and hence the foundation program had to be conducted through an online platform. The present paper is a description of the online program conducted in the institute and is aimed to focus on the pros and cons of using an online platform for conducting the program and the experience gained from it. The online foundation program was conducted over a period of 16 days through the Zoom ${ }^{\odot}$ platform. The program was tailored to cater for the orientation of 175 students who were admitted for first year MBBS batch 2020-2021. Feedback from students was obtained through Google Forms $^{\odot}$ at the end of the program. The online program was conducted smoothly due to the dedicated efforts of all the team members. Sessions requiring hands-on training and physical field visits had to be omitted in the present program. Network connectivity issues were reported sometimes. The conduction of the online foundation course program was indeed a learning experience. The team work was well reflected in the feedback from the students, which revealed appreciation for the overall program. Many sessions went very well in the online mode; however, sessions on humanities and extracurricular activities could have been organized in a better way with the physical presence of the students.
\end{abstract}

Keywords: orientation, Zoom $^{\odot}$ platform, students, modules

\section{Introduction}

Foundation courses are conducted by universities across the globe to induct the newly admitted students to various courses. This helps the students to get comfortable in their new environment and they can interact with their peers and mentors. ${ }^{1}$ Similarly, in medical schools, foundation courses introduce the medical students to the new environment and form a significant part of training for undergraduate medical students. ${ }^{2,3}$ The induction sessions prime them to the roles and responsibilities towards the patients and the country where they have to practice throughout their life and also pass on to their successors. ${ }^{4}$ This enables the young, enthusiastic medical undergraduates who are generally under a protective environment in their homes, under the guidance of their parents/guardians, to live responsibly on their own and strike a work-life balance. ${ }^{5,6}$

The modules in the foundation course are designed such that the students are oriented to the different tiers of health care delivery and understand their position 
among the stakeholders of the system. The program aims at their overall personality development and hence sports and extracurricular activities are also incorporated. ${ }^{5}$ Group-activities in these programs bring out creativity and inculcate team spirit among students for developing a problem-solving mindset among the students originating from different parts of the country who would now be staying and learning together for another five and half years.

There has been an increasing gap between society's expectations and delivery of health care and hence the medical students have to be trained in a way that they imbibe the practice of showing empathy towards patients from the inception of their medical curriculum. ${ }^{7}$ According to the recent guidelines laid down by the National Medical Council (NMC) (previously known as the Medical Council of India (MCI)) in the Competency Based Curriculum for the Indian medical graduates, the relevance of the orientation program has been well emphasized and is mandatory for first year MBBS students. ${ }^{8,9}$ The program is developed with a focus on learning soft skills and adequate communication etiquettes at the very beginning of their career, giving them an opportunity to hone their skills. ${ }^{9}$ It is expected that such introductory lessons may better equip students for effective management of and interactions with patients thereby reducing the appallingly abusive behavior towards the doctors being reported everywhere across the country.

The foundation course program is generally conducted every year after students start attending the college after completing all the admission formalities. This year, also, the program was conducted for the new students. However, due to the COVID-19 pandemic, this year the program was conducted through an online platform. This year the admission procedures were delayed owing to the pandemic and waiting for students' physical presence on the campus was meaningless, as the sessions were already postponed and had to be conducted through an online mode. The entire conduction of the program was a new experience for faculty members who were involved in organizing and scheduling the program, recruiting resource faculty especially for online mode, and coordinating with administrative staff, technical staff and students.

In these unprecedented situations, it becomes imperative to understand that distance learning has helped to prevent academic loss at all levels of education across the globe. However, implementation of exclusive online teaching and learning has been a new learning experience for everyone and the shortcomings are being rectified continuously in the process to develop a well-organized system of online education. In the sequence, the present study is a narrative of the steps taken to conduct an online foundation program for the first year medical undergraduate students successfully during the present COVID-19 pandemic, the difficulties and challenges faced during the program, experiences and learning gained from it to improve the program in future.

The present study was approved by the Institutional Ethics Committee of the All India Institute of Medical Sciences, Rishikesh, India (AIIMS/IEC/21/251).

\section{Preparations Before Starting the Foundation Course}

The preparations for the orientation program started with constitution of a "Foundation course committee". The committee was comprised of six members and they were vested with the responsibility for planning the program, interacting with the higher administrative authorities, coordinating with resource faculty, and interacting with IT personnel and other staff for smooth conduction of the entire program.

The committee members conducted several meetings for planning and execution of the program. The program was prepared for orientation of 175 students. Thereafter, the members prepared a final schedule of the program and obtained requisite approval from the higher administrative authorities of the institute. The institute administration purchased subscription for conducting the program on the Zoom $^{\odot}$ platform.

\section{Identification of Speakers for the Sessions}

The resource faculties for various sessions were identified from both within and outside the institute. Some speakers who had been part of the orientation program as resource faculty for various sessions in previous years were invited again. In addition, many new distinguished orators from different fields were invited to give their talks. The program organizing committee members had the responsibility to contact all the speakers, confirm their participation and inform them in advance regarding their sessions.

\section{Sessions of Foundation Course}

The online foundation course program was conducted over a period of 16 days. Four sessions were conducted each day. 
Each session was of 1-hour duration and the speakers would deliver their talk for about 45-50 min while the remaining time was utilized for interaction with students. Some of these sessions in the induction module were in the form of didactic sessions whereas the rest of the sessions were in the form of interactive sessions in which the students had to actively participate. The speakers used PowerPoint slides, audio or videos as teaching tools for the sessions. The sessions were kept interactive as the students could interact with the speakers. The students interacted directly as they had provision to unmute their mics and could also post their comments in the chat box which could be accessed by the speakers.

These sessions were categorized into modules, namely: induction module; professional development module; community orientation module; patient care module; COVID module; modules for research; computer skill enhancement; module on holistic treatment approach; and soft skill module (Table 1). The modules were prepared according to the guidelines of Competency Based Medical Education (CBME) laid down by NMC. ${ }^{3}$ The modules were comprised of various sessions that were conducted in the past for the previous intakes but in the present program the COVID module was introduced which had sessions on the history of outbreaks, epidemics and pandemics, overview of COVID-19 pandemic and infection control practices, with an emphasis on hand hygiene, bio-medical waste management and use of Personal Protective Equipment (PPE) kit. Although a few sessions on extracurricular activities were a part of the foundation program in previous years, about ten sessions on humanities were added to the course this year. Dedicated and experienced faculty took introductory sessions on various arts like drama and theatre, dance, painting, photography, narratives and reflections, and doodling art (Supplementary Table S1), emphasizing the importance of humanities in our lives, how they prevent burnout in a medical profession and promote an overall development of the medical undergraduates. Although, students were not living together on the same campus, the e-exhibition helped the students know each other's talents and interests further, leading to the idea of creating hobby clubs based on shared interests.

\section{Role of Information Technology Cell and Academic Section Staff}

A vital role was played by the staff of the academic section and information technology (IT) cell in the online program. The IT staff were always available to help out with any kind of connectivity issues and duly helped the resource faculty
Table I Modules and Their Contents for the Orientation Program

\begin{tabular}{|c|c|}
\hline Module & Details \\
\hline Induction module & $\begin{array}{l}\text { To introduce the students to the medical } \\
\text { curriculum, life on campus, historical aspects } \\
\text { of health care, their roles and responsibilities } \\
\text { as stakeholders of the health care system }\end{array}$ \\
\hline $\begin{array}{l}\text { Professional } \\
\text { development module }\end{array}$ & $\begin{array}{l}\text { To introduce the students to the ethics and } \\
\text { behavior of a doctor, importance of } \\
\text { mentorship, effective communication skills, } \\
\text { emphasis on time management skills, } \\
\text { awareness of mental health and stress } \\
\text { management in a new environment }\end{array}$ \\
\hline $\begin{array}{l}\text { Community } \\
\text { orientation module }\end{array}$ & $\begin{array}{l}\text { To orient the students to family medicine } \\
\text { practices and their relevance, role of doctors } \\
\text { in society }\end{array}$ \\
\hline Patient care module & $\begin{array}{l}\text { Introduction to first aid for some common } \\
\text { diseases/injuries for a beginner, ethics for } \\
\text { practicing medicine, relevance of } \\
\text { documentation }\end{array}$ \\
\hline Research module & $\begin{array}{l}\text { To introduce the students to the concept of } \\
\text { medical research, patents, innovations }\end{array}$ \\
\hline $\begin{array}{l}\text { Computer skills } \\
\text { enhancement }\end{array}$ & $\begin{array}{l}\text { To introduce the students to common IT } \\
\text { skills used in medical practice }\end{array}$ \\
\hline $\begin{array}{l}\text { Holistic treatment } \\
\text { approach }\end{array}$ & $\begin{array}{l}\text { To emphasize holistic health and lifestyle } \\
\text { management, meditation and yoga for } \\
\text { healthy living }\end{array}$ \\
\hline COVID module & $\begin{array}{l}\text { To introduce the students to the concept of } \\
\text { pandemic/epidemic diseases with emphasis } \\
\text { on COVID, hand hygiene practices, infection } \\
\text { control }\end{array}$ \\
\hline Soft skills & $\begin{array}{l}\text { To introduce the students to effective } \\
\text { communication skills, concepts of empathy, } \\
\text { working as a team, management of conflict }\end{array}$ \\
\hline
\end{tabular}

who faced any problem in running their presentation or interacting with students. The academic section staff had the imperative responsibility of generating URL links for daily sessions and sharing them with the resource faculty, members of the organizing committee and all the students. They also helped in sharing any kind of official communication from the committee members or resource faculty through mail to students and vice versa.

\section{Feedback from Students}

Feedback for the program was obtained through Google Forms ${ }^{\circ}$. The form was prepared by the organizing 
committee members and the link was shared with the students at the end of the program. The feedback questionnaire was prepared with a focus on how they would rate the content of the sessions, whether they were engaging and interactive and whether the program was properly conducted. The feedback was approved by all the faculty members of the committee. These feedbacks were aimed to analyze the program and help in improvement in future.

\section{Organization of e-Exhibition}

In the previous years, the foundation course program concluded with extra-curricular performances by the students; however, this year the entries for such performances from interested students were received in the form of videos of dance performances, song audios, memes, photographs, and paintings and were displayed as an e-exhibition on the last day through the online Zoom ${ }^{\complement}$ platform. These entries were played one after the other, giving students an opportunity to showcase their talents and creativity (Figure 1).

\section{Critical Analysis of the Program from Organizing Committee Members' Perspectives}

The organizing committee members were comprised of members who were also part of the committee in previous years except for two new members who were included this year. The members felt that, although organizing the program in an offline mode and interacting with students in person is always interesting and effective compared with a virtual platform, considering the present pandemic situation, there was no alternative. The online conduct of the program was entirely a new experience for every member; however, in the process they appreciated that the program was conducted well on the online platform. All the resource faculty were quite cooperative and had happily agreed to be a part of the program, although a few were apprehensive about the virtual platform. The support from administration, the IT cell of the institute, and academic section staff was highly motivating.

Online conduct of the program had its own pros and cons and it was reflected even in the present program. The online platform provided the faculty across the country with an efficient way to deliver their sessions and interact with the students. They could easily contribute to the program from their own offices. The committee members were able to moderate the sessions, share feedback links and receive them in their working areas. Obtaining feedback was much easier in the present program. The students were able to attend the sessions from their place of residence. These sessions could be recorded, archived or shared with the students for future use. Use of audio or
A

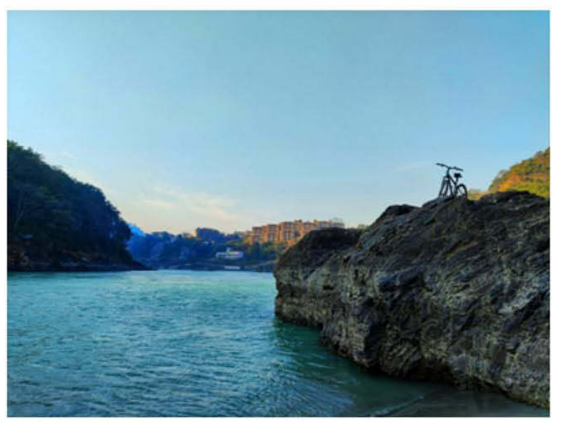

C

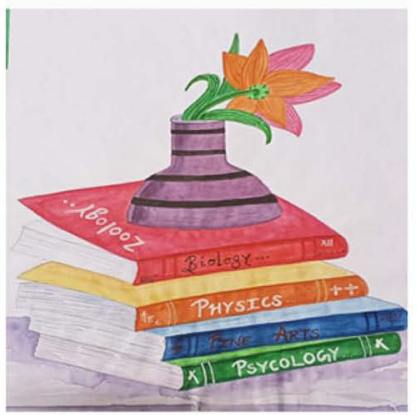

D

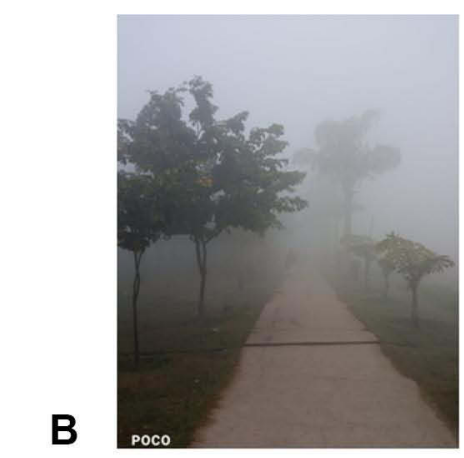

Figure I E-exhibition entries- (A and B) Photographs clicked by students. (C and D) Sketches drawn by students. 
video clips was also easy. The majority of students attended the sessions. There were high level interactions among the speakers and the students. The e-exhibition was well organized and students showed great enthusiasm and shared their entries and the program seemed to be a perfect platform to showcase their talents even in this unprecedented situation.

The major pitfall of this online program was that there was no physical interaction among students and the faculty, which somehow takes away the warmth of mentor-mentee interaction. The peer learning process cannot be developed in online learning. Further, while delivering their talks the speakers remained unaware of how many students were actually attending their session since the students would keep their microphones and cameras off. At times, if a student kept them on, then there were disturbances in the form of unwanted background sounds. During interaction with students, only some of the students would participate in interaction and others remained silent. This lacuna was well expressed during conduct of humanities sessions where students' participation played a pertinent role. This nonparticipation is generally overcome during a physical class where interaction is much better.

At times, students would chat among each other in chat box if the host forgot to block the chatting facility during their talk. Similarly, students could put annotations on the screen shared by the speakers if the host missed disabling the facility for students. Faculty training for using online platforms remains a big issue in online teaching.

Technical issues in the form of poor internet connectivity were reported at times by some students. Inconsistent networks would lead to disruption of continuity in sessions and the students would lose interest in it. Further, it is reported that prolonged hours of online sessions expose the students to various problems in the form of poor posture and effects on vision, which lead to poor attention span. $^{10}$

In previous years, the foundation course program had modules on training for Basic Life Support (BLS) and hand hygiene, in which students used to get hands-on training. However, in this year's program such modules could not be conducted. Every year the students are taken for visits to campus, hospital, primary health care centers, villages, and geriatric care centers, so that they are primed for patient care. However, this time the students could not be taken for campus visits and field visits in the present program and only pictures of these places were displayed.
The students could not get the real time exposure for these sessions.

\section{Learning Moments}

The experience of conducting the online foundation course program was a great learning opportunity. The online program helped to bring out the strengths and weaknesses in the orientation program. It became clear that humanities sessions serve their purpose best when conducted in the physical presence of and live interaction with students. Although it may not be the best idea to present humanities on an online platform owing to lack of interaction, it is still a good idea to introduce the concepts, make hobby clubs and understand their interests so that their minds are prepared when the opportunity for physical presence is available. Moreover, the institute gets time to prepare according to the students' interests. Such activities, though restrictive due to online mode, also have the scope of breaking the monotony of serious didactic subject lectures. Further, a time gap has to be provided between two consecutive sessions in order to avoid monotony. Students had to be constantly prompted to interact during the sessions.

\section{Measures to Be Taken While Developing Online Orientation Program}

During the process of developing the online orientation program, it is pertinent to keep in consideration that a highly dedicated team is required to organize the program successfully. Hence, responsible and dutiful members must be incorporated in the team at each level. Administrative and financial approval for hosting the program must be taken in advance in order to avoid any last moment crisis. An online platform subscription for online platform must be purchased according to strength of students participating in the program and duration of sessions. A blueprint for conducting individual sessions must be prepared. Speakers for each session must be identified. The speakers need to be informed in advance of their sessions and, if needed, a few members of the team may interact directly with the speakers to apprise them regarding content of session desired for the students to be addressed, confirm for the availability on days of their respective sessions, teaching tools needed by the speakers, etc. Guidelines for the technical team must be laid down, so that they can coordinate the sessions smoothly. A few members of the team must be allocated 
with responsibility for generating links and sharing with students as well as speakers, preparing feedback forms, and evaluation. Moderators for the sessions must be deputed. Sessions on extra-curricular activities or humanities need extra efforts in the form of motivating students to show their participation as some students are reluctant. They need to be monitored constantly and if many students are attending, then it becomes difficult to keep track of each one at a time. The speakers/faculty need to be well versed with the online platform which they have to use for their presentation.

\section{Conclusion}

Organizing online orientation programs needs a strong and dedicated team effort. Members in the team involve people who work in different departments at different grades in the same institution. Hence, coordinating such programs needs timely preparation and incorporation of more staff and faculty so that the live sessions are conducted smoothly. It must be agreed that it is difficult to replace the physical classroom experience; the online platform serves as an alternative feasible mode to conduct orientation programs for the newcomers in situations of crisis, such as the present pandemic.

\section{Disclosure}

The authors report no conflicts of interest in this work.

\section{References}

1. A guide to student induction program-UGC. Available from: https:// www.ugc.ac.in/pdfnews/0559509_A-Guide-to-Student-InductionProgramme.pdf. Accessed May 17, 2021.

2. Mahajan R, Gupta K. Evaluation of orientation program for fresh MBBS entrants: faculty and students' perspectives. Int J App Basic Med Res. 2015;5:S50-S53. doi:10.4103/2229-516X.162278

3. Mittal R, Mahajan R, Mittal N. Foundation programme: a student's perspective. Int J App Basic Med Res. 2013;3:52-54. doi:10.4103/ 2229-516X.112241

4. Misra S, Fichadiya N, KariYa V. Implementation of foundation program under "graduate medical regulations 2019" for first professional MBBS students at a medical college located in western India a transformative learning experience. MedEdPublish. 2020;9(1):64. doi:10.15694/mep.2020.000064.1

5. Senthil Velou M, Ahila E. Foundation course for first year MBBS students in India - disparity between its intentions and implementations. IAIM. 2020;7(8):91-96.

6. Francis A, Kotturan AD, Kuttichira PL. Orientation program to MBBS course at a missionary run medical college in Kerala: analysis of students' feedback. Int J Res Med Sci. 2018;6(8):2758-2762. doi:10.18203/2320-6012.ijrms20183265

7. Chaturvedi R, Gupta RR. Foundation course for undergraduate medical education program: a stitch in time. J Med Acad. 2019;2 (2):37-38.

8. UG Curriculum. NMC. Available from: https://www.nmc.org.in/infor mation-desk/for-colleges/ug-curriculum. Accessed February 13, 2021.

9. Foundation Course - NMC. Available from: https://www.nmc.org.in/ wpcontent/uploads/2020/08/FOUNDATION-COURSE-MBBS-17. 07.2019.pdf. Accessed May 17, 2021.

10. Pros and cons of Online education. Available from: https://www.ies. ncsu.edu/resources/white-papers/pros-and-cons-of-online-education/. Accessed May 15, 2021.
Advances in Medical Education and Practice

\section{Publish your work in this journal}

Advances in Medical Education and Practice is an international, peerreviewed, open access journal that aims to present and publish research on Medical Education covering medical, dental, nursing and allied health care professional education. The journal covers undergraduate education, postgraduate training and continuing medical education

\section{Dovepress}

including emerging trends and innovative models linking education, research, and health care services. The manuscript management system is completely online and includes a very quick and fair peer-review system. Visit http://www.dovepress.com/testimonials.php to read real quotes from published authors. 